\title{
画像処理技術によるオンライン・樹脂ペレット外観検査/自動選別 制御システムの開発
}

\author{
志澤達司
}

出光石油化学 (株)，299-0193 市原市姉崎海岸 1-1

\begin{abstract}
樹脂製造プロセスのオンライン・ペレット外観検査/不良品自動選別制御システムを開発した.本外観検 查システムは画像処理技術を活用したもので, 50 100 $\mu \mathrm{m}$ 程度の樹脂ペレットの異物を, サンプリングか ら検查，検查済の試料の排出処理まで自動で行い，光の測定結果により，製品サイロ又は，不良品サイロ への自動切り換元制御を実行する。 本システムの開発により，品質の安定・製造装置の安定運転・省力化の向上を図ることができた。
\end{abstract}

\begin{abstract}
緒
樹脂ペレットの品質特性の一つに色調, 変色, 異物などのペレ ット外観がある. 熱可塑性樹脂の場合, 異物（樹脂劣化物及び樹 脂以外のもの)が樹脂中の混入すると成形品のフィッシュアイ(透 明なフィルムの中に $0.2 \sim 0.3 \mathrm{~mm}$ 程度の透明または不透明粒子 が存在すると魚の目のようにその周辺が円形に拡大されて見える 外観不良）の核になる，成形品表面に印刷が乗らない等の品質低 下の原因となることが知られている.

志澤の研究 (Shizawa, 1991) によると, 熱可塑性樹脂（以下, 樹脂）の異物検査は, 成形加工（フィルム, 射出, プレス成形な ど）をして異物を発見しやすくして検查する方法，樹脂を溶剂で 溶解・沪過し，沪紙上に異物を捕捉して検查する方法, ペレット の状態で直接検查する方法, などが行われてきた. 成形加工と溶 剂にて溶解・沪過し，沪紙上に異物を捕捉する方法は測定前処理 に時間がかかり, 異物の有無, 量などの試験情報を製造工程にフ イードバックするまでに多くの時間を費やすという欠点がある. 一方, ペレットの状態で直接検査する方法は測定前処理もなく, 検査情報のフィードバックは早い. しかし，ペレットが米粒状の 形態の為, 検査の自動化が困難で, 目視検査を基本とした官能検 查を余儀なくされていた。

本論文では，目視レベルの異物を対象とした画像処理によるオ ンライン・ペレット外観検査システムを試作し，それを活用した 異物ペレット選別制御システムを開発したので，その内容を報告 する.
\end{abstract}

\section{1. 目視検査および開発のターゲット}

目視による異物検查の限度は, 青山の研究 (Aoyama, 1994), 中村の研究（Nakamura, 1984）で約 50〜75 $\mu \mathrm{m}$ 程度である.そ こで，オンライン・システムを構築するに当たり，システムの検 出下限は $50 \mu \mathrm{m}$ 程度を目標とした，人による目視検查は，異物の 個数や形状（例之ば繊維状異物，金属光沢のある異物，樹脂劣化 物）を同時に判別できる.しかし，検查員にかかる負担が大きく， 検查感度が人により各々異なるという官能検查特有のバラツキ要 因や検查感度を維持できる時間の制約などの問題を抱えている. 今後, 熟練の検查員を集めるのは大変になってくる.ここで, 検 查員 5 名による同一袋ペレットの目視検査結果を Table 1 に示す.

† 1997 年 9 月 29 日受理
このように，人による目視検查は，疲れ，バラッキ，検出下限 などに問題があり, 異物の外観検査の機械化の必要性が高まって きた。そこで著者は, サンプリングや前処理時における異物の混 入の問題も合わせて考慮したトータル的なオンライン検査/ペレ ット選別制御システムの構築をめざした.

樹脂ペレットは, 無着色のナチュラル品と, 着色・ガラス䋐維 混合品などのいわゆる二次加工品とがある. 本システムはまずナ チュラル品をターゲットとし, その応用で二次加工品に着手する こととした

以上まとめると, 著者はナチュラル品の異物（樹脂劣化物で有 色なもの及び樹脂以外の異物）を，人による目視検査の検出下限 $50 \mu \mathrm{m}$ 程度でオンライン検査するシステムを開発した.

\section{2. 樹脂ペレットのオンライン・異物検査の原理}

樹脂ペレットの異物をオンラインにて検査する方法は本報文の テーマであるペレット外観検査機にて検査する方法と, 特許情報 (Shimokawa and Saeki, 1985; Maeda et al, 1995) 等による樹 脂が溶融状態において樹脂を透過する光を発生する光源と, 樹脂 を透過した光を受光する受光器とを備之, 受光器からの光検知信 号にもとづいて光の透過率の差により樹脂中の異物を検出する方 法がある。

樹脂を溶融状態にし異物検査する方法は，センサーの耐熱性， 流路部分/分岐部の偏流から, 樹脂滞留による樹脂の劣化の問題が 考えられる. 高野の研究( Takano, 1996) によると, 樹脂を溶融 状態にした成形機内スクリュー表面上での異物について報告され ている. 一方, 樹脂の品質を悪化させる異物は, 樹脂ペレットの 表面に付着している「付着異物」と，樹脂に練り込まれまれてい る「練込異物」の二種類がある。このうち, 「付着異物」は, 外部 からの混入とともに, 樹脂を米粒状に切断するときに発生する. 樹脂を米粒状に切断する時に発生する異物（その多くは, カッテ ング刃とダイス部及び樹脂による摩擦発熱による樹脂劣化物と考 えられる）は, 最適のカッテング刃を選定しても完全に発生を抑 えることは困難であると考えられる.

そこで，人による目視法に代わって，樹脂の品質を考える場合， 樹脂のペレット状態にて練込異物と付着異物の両方を検査できる システムが必要となる。

\section{3. ペレット外観自䃼検査システムの試作}

現在, ペレット外観自動検査機は大きく分けて 2 種類の検出原 
Table 1 Repeatability test (5-members) of man's inspection for pellets check

\begin{tabular}{lc}
\hline members & $\begin{array}{c}\text { man's inspection } \\
{[\text { count } / 500 \mathrm{~g}]}\end{array}$ \\
\hline A & 10 \\
B & 26 \\
C & 7 \\
D & 22 \\
E & 9 \\
Mean & 14.8 \\
standard deviation & 8.58 \\
CV \% & 58 \\
\hline sample & \\
LLDPE (0134H, Idemitsu Petrochemical Co., \\
Ltd.)
\end{tabular}

理がある. 1つは色差をセンサーにて判別するもので, Nelsonの 研究 (Nelson, 1979), 部屋の研究 (Heya, 1991) によると, 穀物 などの異物検查選別機（例之ば米の精米過程で, 石, ワラクズ, ゴミ等を取り除く機器）を改良したもので，この機器の異物の検 出下限は一般的に $500 \sim 1000 \mu \mathrm{m}$ 程度である.もう 1 つは, 画像処 理技術を応用したもので, 数 $\mu \mathrm{m}$ 程度の異物まで測定可能であ る. しかし, データ処理スピードとコストの関係から, 現在, 実 用化されている検查機の検出下限は 50〜 300 $\mu \mathrm{m}$ 程度のものが各 メーカーから市販されている.

運転実績からオンライン・外観検査システムの異物検出下限 目標は $50 \mu \mathrm{m}$ 程度であることから, 今回は, (株) 日本アルミ社製 のペレット外観検査機をベースに, Fig. 1 に示すオンライン検査/ 選別制御システムを構築した. Fig. 1 において, 押出機から出てき たペレットはその一部分を自動的に分取され，異物の検査をぺレ ット外観自動検查機により検查する. その検査結果により異物が 設定值より多ければ不良品サイロに自動的にバルブを切り換える. 異物数が設定值より少なければ，自動的に製品サイロに切り換之 る. 又, 異物が非常に多い場合は押出機に信号を送り押出機先端 のフィルターの交換, 押出機の停止を行うシステムである.

ペレット外観自動検査機を Fig. 2 に示す.この検査機は, ペレ ットは回転しているテーブル上に落とし，照明ユニットにより最 適な照明光を与え，カメラにより捕らえられた画像情報は検査工 ニットにて演算され, 異物サイズのランク分けと個数を出力する. 画像処理ソフトは侏日本アルミ社製を活用した。

\section{4. 全自助システム化の構築}

全自動システム化の構築における問題点及び改善点は, 次の 4 点に分類できる.

（1）検査機のチューニング，（2）検査環境，（3）サンプリング及 び試料の排出，(4) 検查信号の扱い方である.これらの問題はシス テムの信頼性に密接に結びついている.

\section{1 検查機のチューニング}

検查機のオンライン使用, オフライン使用を問わず, 検査機の 能力を最大限に活かす為には, 焦点・光量・絞りの調整が重要な ポイントとなる.

ここで, ペレット外観自動検查機の画像処理部の構成を Table 2 に, 調整例を Table 3 に示す.

焦点合わせは $1 \mathrm{~mm}, 2 \mathrm{~mm}, 3 \mathrm{~mm}, 4 \mathrm{~mm}$ の階段状にガラスゲー ジを作成し, 各々の階段に $50 \mu \mathrm{m}, 100 \mu \mathrm{m}, 150 \mu \mathrm{m}$ のマーキング をしたものを用いた，光量は目視にて選別した異物入りペレット

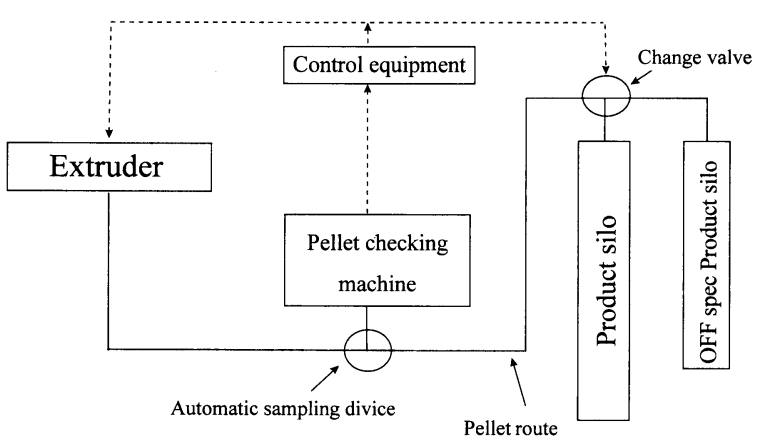

Fig. 1 On-line pellets automatic testing and selecting control systems

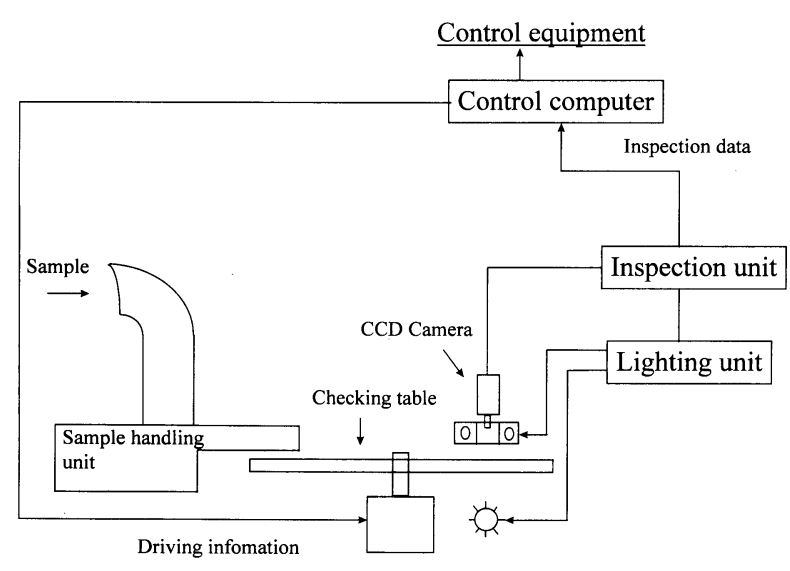

Fig. 2 Pellets testing machine system

を用い, 異物を検出し, ペレットの重なり部分がノイズとして検 出しないように調整した.

オンライン化するに当たり, 樹脂の劣化が進行していない茶色 異物をも同時に検查できるものとした。

茶色異物を劣化度が進んだ黒色（焦げ茶色）異物と同様に検査 するには，茶色と補色関係にあるフィルターを挿入すると良い。 当然のことながら，フィルターを挿入するとレンズの絞りを開け， 焦点深度は浅くなるという欠点はあるが，オンラインで使用する 場合, 樹脂の劣化度の初期段階である茶色異物を検出することは, 押出機の運転上重要な情報となる.

今回，ポリエチレン装置に活用したフィルターを Table 3 欄外 に示す.フィルターを挿入することにより絞りは 5.6 から 2.8 unit となった.フィルター及び絞りは各目的試料（樹脂）の最適 なものを実験により選択した。

調整用のモデルサンプルは, 造粒する前のポリカーボネートパ ウダー(出光石油化学社製, FN 1500)に，44〜74 $\mu \mathrm{m}$ に分級した 鉄粉（SUS 304 粉）を入れて作製した. また他の検査法との比較 のため, モデルサンプルを電子工業用メチレンクロライドに溶解 して，沪過し，沪紙上に異物を捕捉し，捕捉した異物（鉄粉）を 目視にて測定した (以下溶解沪過法と称する)．鉄粉混入量と外観 検查機のカウント数の結果を Fig. 3 に，また，溶解沪過法と外観 検査機のカウント数を Table 4 に示す. 溶解沪過法と外観検查機 のカウント数は同等の結果と考える.

ここで性能確認のためのモデルサンプルとしてポリカーボネー トパウダーを選定した理由は,

(1) 押出機において熱履歴を受けていない為, 押出機に起因す るノイズを考える必要がない.

(2) ポリカーボネートは室温で容易に溶ける溶郕があり, 異物 
Table 2 Configulation of image processing for resin pellets automatic testing machine

\begin{tabular}{ll}
\hline CCD Camera & $\begin{array}{l}\text { XC-77 } \\
\text { (SONY) }\end{array}$ \\
Lens & FUJINON CF75A \\
& (FUJI PHOTO OPTICAL CO., LTD.) \\
Inspection unit & F8-013 \\
& FF-5993AN II \\
& (HAJIME INDUSTRIES, LTD.) \\
Lighting unit & CF-80NBH-W \\
& (HAJIME INDUSTRIES, LTD.) \\
Control computer & PC-9801-BX3/U2 \\
& (NEC) \\
Sample handling unit & FOOB \\
& (SHINKO ELECTRIC CO., LTD.) \\
Checking table & Checking table \\
& (NIPPON ALUMINUM CO., LTD.) \\
\hline
\end{tabular}

Table 3 An adjustment of pellets testing machine

\begin{tabular}{ll}
\hline Focus & up to $1 \sim 4 \mathrm{~mm}$ from testing table \\
Exposure scale & 5.6 unit \\
Amount of light & upper light 2 unit \\
& lower light 3 unit \\
& $512 \times 480$ bite \\
Analyze ability & $7 \times 8 \mathrm{~mm}$ \\
Inspection area &
\end{tabular}

on-line testing system for polyẹthylene plant

Filter V-44 (TOSHIBA GARASU CO., LTD.)

Exposure scale 2.8 unit

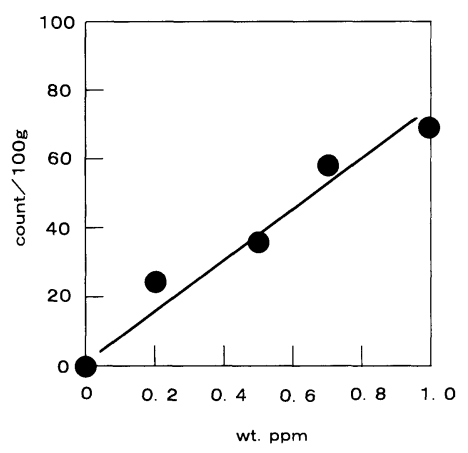

Fig. 3 Typical testing result of model sample for powdered iron's quantity in polycarbonate powder

モデルである鉄粉を回収し易い。

の 2 点である. 樹脂パウダーにて性能確認をした後, 樹脂ペレット

に展開することとした。

ポリエチレン樹脂用に設定した検査条件での同一袋より採取し た試料における 10 回の繰り返し検查結果を Table 5 に示す.人 による検査（Table 1）に比較して検査精度が良いことがわかる.

\section{2 検 查 環 境}

オンラインで検査するメリットの 1 つに, サンプリング時, 試料 移送時，測定時の付着異物の混入防止がある。検査環境はJIS B 9920 のクリーン度クラス 7 (FED-STD-209 D クラス 10000) 程 度以上のクリーン度の検査環境を設定し, 検査機にクリーンユニ ットを設置し検査機の検查部のクリーン度を保つシステムとした。 また，樹脂ペレットどうしの擦れから静電気が発生することを考 慮し, 検査ペレットがペレット搬送設備から回転しているテーブ ル上にペレットを落とすところにイオン化エアーを照射する対策 をとった。これは, 季節, 湿度などの環境からの影響, 添加剂処 方にもよるが，200～300 g のポリエチレン樹脂をポリエチレン袋 に入れて数回上下に振ると数 $\mathrm{Kv} \sim 10$ 数 $\mathrm{Kv}$ の帯電が観察され，
Table 4 A comparsion between dissolved-filtration method and resin pellets automatic testing machine

\begin{tabular}{ccc}
\hline $\begin{array}{c}\text { Powderd iron's } \\
\text { quantity } \\
\text { [wt. ppm] }\end{array}$ & $\begin{array}{l}\text { Pellet sesting } \\
\text { machine } \\
\text { [count/100 g] }\end{array}$ & $\begin{array}{c}\text { Dissolved } \\
\text {-filtration } \\
\text { method } \\
\text { [count } / 100 \mathrm{~g}]\end{array}$ \\
\hline 0 & 0 & 0 \\
0.2 & 23 & 27 \\
0.5 & 36 & 35 \\
0.7 & 59 & 64 \\
1.0 & 69 & 66 \\
\hline
\end{tabular}

Table 5 Repeatability test $(n=10)$ of pellets testing machine

\begin{tabular}{cc}
\hline $\mathrm{n}$ & $\begin{array}{c}\text { Pellet testing machine } \\
{[\text { count } / 500 \mathrm{~g}]}\end{array}$ \\
\hline 1 & 5 \\
2 & 6 \\
3 & 5 \\
4 & 7 \\
5 & 7 \\
6 & 5 \\
7 & 7 \\
8 & 5 \\
9 & 4 \\
10 & 7 \\
Mean & 5.8 \\
standard deviation & 1.14 \\
CV \% & 20 \\
\hline sample & \\
LLDPE (3500Z, Idemitsu Petrochemical Co., Ltd.)
\end{tabular}

それを中和する為に用いた。

\section{3 サンプルリング及び試料の排出}

4.3.1 サンプリング 人による目視検査の場合, サンプル採 取時のコンタミネーションが問題となるが, オンラインで検査す る場合はサンプル採取時のコンタミネーションの危険はなくなる。 オンラインにてペレット外観を検查する場合, 配管内を移動して いるペレットからのサンプリング，ストックされている容器から のサンプリングを自動的にする必要がある.

自動的にサンプリングされた試料は計量せずに異物の推移をモ リタリングする方法もあるが，製造装置の運転変動などでペレッ 卜量が変動する可能性があるので試料の計量が必要となる，本シ ステムでは，ペレット外観を検査する前にペレットを計量するシ ステムを採用した。

4.3 .2 試料の排出 人による目視検査は,ペレットの外観不 良の種類が検査しながら判別できるが，オンライン・検査システ ムは, ペレット外観不良の数が増加したか, 減少したかの情報し か出力されない，そこで，検査の終了したペレットは系外に排出 する時, 良品ペレットと不良品ペレットに分別して排出するシス テムとした

\section{4 検査信号の取り扱い方}

異物の検査結果は異物の大小により重み付けをする必要がある。 大きな異物は製品中に混入してはならず，各異物のサイズランク により設定值を決め, どの異物サイズでも異物のカウントが設定 值を超えると検査途中であっても自動的に製品（良品）サイロか ら不良品サイロにバルブが切り替わるシステムにする必要がある. ここで，ランク分けサイズは，検査エリアと画素数との関係か 


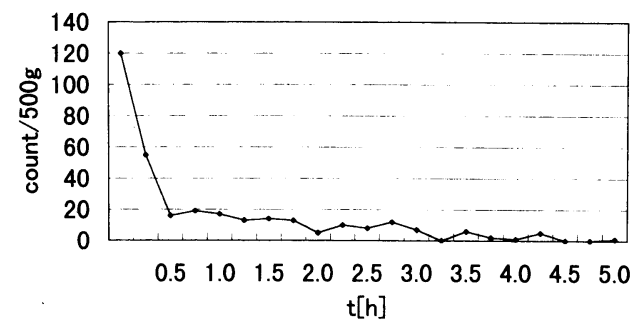

Fig. 4 Typical testing result of on-line resin pellets external testing system in a polyethylene plant

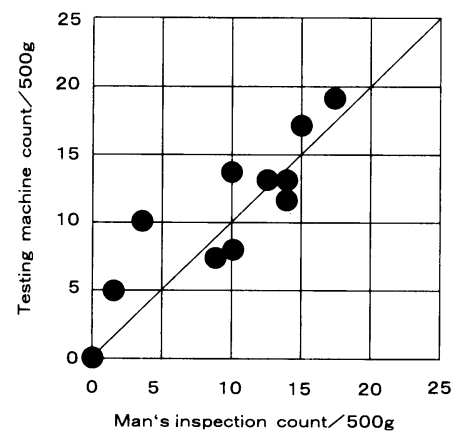

Fig. 5 Fitness between man's inspection and pellets automatic testing machine

ら自動的に決まる.本システムでは,ノイズを考虑して 2 画素連続 の異物を最小カウント単位とした. すなわち, 検査の 1 辺 $(=8$ $\mathrm{mm}) \div 480 \times 2=33 \mu \mathrm{m}$ が理論的な異物のカウント単位となる。こ の数值の倍数により異物サイズのクラス分けがなされ，樹脂の特 性, グレードの特性により設定值を変える必要がある．本システ ムでは, 34〜 67 $\mu \mathrm{m} の$ 範囲を $50 \mu \mathrm{m}$ と設定した.

不良数が增加した場合, 製品のコンタミネーションを防止する 観点から前述のごとく自動でサイロを切り替わるシステムとする が，「何の不良でカウント数が増加したのか」が，前項の不良品ぺ レット情報が装置の運転情報として重要となる。

\section{5. オンライン・ペレット外観検査機性能評価}

開発したオンライン・ペレット外観自動検査機は, 試料の採取 からペレットの検査, 結果の出力まで人手を介さずに, 15 分毎に $500 \mathrm{~g}$ のペレット検査を全自動で行う。該機をポリエチレン装置 に設置し，時系列データを採取したその結果をFig. 4 に示す. 本 データは樹脂の押出機がスタート直後のカウント数の推移を示し たものである．押出機スタート後の異物推移がリアルタイムにわ かる.このことから, 本システムは装置安定運転・品質の安定に 大きく寄与することがわかる.

尚，分別回収されたペレット中の不良品ペレット数と検查機に よるカウント数は同じであった。

カウント数が $20 / 500 \mathrm{~g}$ 以下になったペレットを検査機に投入 されると同時に採取した試料の, 人による目視検査 (検査員 1 人に 固定）とオンライン・ペレット外観自動検査機のカウント結果を Fig. 5 に示す.

人によるペレット目視検查の変動係数は $58 \%$ で, オフラインに て確認したペレット外観自動検查機の変動係数は $20 \%$ であるこ とを考慮すると，オンライン・ペレット外観自動検査機の測定結 果は人による目視検査と同レベルであることがわかる.

尚，人による目視検查にて検出下限 $50 \mu \mathrm{m}$ 程度を維持しつつ
$500 \mathrm{~g}$ のペレットの外観検查をするには約 1 時間の検査時間が必 要となることから，オンライン・ペレット外観自動検查機と同数 の検査デー夕を人による目視検査にて得る為には最低 4 名の検査 員, 1 時間検査後 1 時間休憩とした交代要員を含めれば 8 名, それ を 8 時間勤務の 4 直 3 交代にて運用すれば $8 \times 4=32$ 名分の膨大 な検査人員を必要とする。

本システムは Fig. 1のフローに示すごとくある規格值 A 以下 にカウント数が入るまで不良品サイロに受入れ，規定值以下にな れば自動的に製品サイロにペレットを受け入れるシステムである。 また運転中にカウント数が規定值 $\mathrm{A}$ を上回れば, 規定量検査の途 中であっても直ちに不良品サイロに切り替わるシーケンスとし， 規定值 $\mathrm{B}(\mathrm{A}<\mathrm{B})$ となれば押出機の自動停止，又は自動で押出機 先端のフィルターの交換を行うシステムである，これにより，装 置の何らかの変動により異物が増加しても，製品中の異物は増加 しない, 即ち, 異物の少ない樹脂ペレットの生産が可能となった。

\section{結}

本論文は，樹脂異物のオンライン・検査機とそれを活用したぺ レット選別制御システムを開発し有効性を実プロセスにて検証し た.

本システムは以下の特徴がある.

（1）樹脂製造装置に本システムを導入し，装置の変動による 異物増加の影響を製品まで影響させないことによる，品 質悪化の少ない樹脂ペレットの生産が可能となった。

（2）樹脂ペレットの外観検査の省力化に，大きく貢献した。

（3）本システムは，樹脂ペレットの異物の推移がリアルタイ ムに把握できるために，装置安定運転に大きく寄与する ことができた。

（4） サンプリングや，試料搬送時のハンドリングがなくなり， 検査時の異物のコンタミネーション防止を図ることがで きた。

今後の課題は，ポリエチレン装置以外への応用展開，知見の蓄 積，改良である。

[謝辞] 本研究にあたって, 東京都立大学大学院工学研究科保母敏 行教授から貴重な指導と助言をいただきました。ここに媣く感謝いたしま す.

\section{Literature cited}

Aoyama, T.; "Measurement of Particle and Sub-micron Particle in Injections," Clean Technology 4, 19-27 (1994)

Heya, Y.; "New Type Particle Inspection \& Elimination Machine," The Plastics, 37, 38-39 (1991)

Maeda, K., Matsuura, K. and Natori, N. ; "Molding Machine of Foreign Substance Inspection Method," Tokkyo Shutugan Koukai Heisei 7-108580 (1995)

Nakamura, T.; "The Latest Optical Technology (10)-Foundation and Application-," Kikai no kenkyu, 36, 1161-1167 (1984)

Nelson, W. J.; "Contamination detector for extruable dielectrics," IEES PES Transm Distrib Conf Expo, 7, 122-125 (1979)

Shizawa, T.; "Study of Pellet Inspection System," Idemitsu Gihou, 34, 458-462 (1991)

Shimokawa, T., Saeki, K. ; "Foreign Substance Inspection System of Melting Plastics," Jitsuyou Shinan Shutsugan Koukai Syouwa 603456 (1985)

Takano, K.; "Molding of Resin and Quality of Molding Product," The Plastics, 42, 2-3 (1996) 


\section{Development of On-line Resin Pellet External Testing and Automatic Selecting Control Systems by using Image Processing Technology}

\section{TATSUJI SHIZAWA}

Chiba Factory, Idemitsu Petrochemical Co., Ltd., Ichihara 299-0193

Key words: application, external testing system, image processing, on-line system.

An on-line automatic resin pellet external testing and automatic selecting control system for substandard products has been developed. The system utilizes the advantage of image processing technology and the testing targets are as small as $50 \sim 100 \mu \mathrm{m}$ foreign substances and discoloration substances in the pellets.

The testing system includes pellets sampling from a plant, testing of sub-standard pellets, and subsequent disposal of tested pellets, and is fully automatic.

The resin pellets are transported automatically to product silo or sub-standard product silo by the selecting control system based on the external testing result. The systems contribute to the stability of quality control and improvement of operation and labor saving. 